\title{
The Effect of Product Placement on Interest in Using Grab as An Online Transportation Services
}

\author{
Girang Razati ${ }^{1, *}$ Nur Gupita Safitri ${ }^{2,}$ Puspo Dewi Dirgantari ${ }^{3}$
}

\author{
${ }^{1}$ Universitas Pendidikan Indonesia \\ ${ }^{2}$ Universitas Pendidikan Indonesia \\ ${ }^{3}$ Universitas Pendidikan Indonesia \\ *Corresponding author.Email: girangrazati@upi.edu
}

\begin{abstract}
This research aims to obtain the influence of product placement on interest in using services. The type of the study is using descriptive and verification. The method used is an explanatory survey with a quota sampling technique of 146 respondents. The data analysis technique is using a simple linear regression with SPSS 24.0 for Windows program tools. Based on the study results, it can be known that the product placement has a partial effect on the interest in using services with a relatively high influence category. The writer recommends that Grab companies can pay more attention to the product placement factor to increase interest in using Grab's online transportation services.
\end{abstract}

\section{Keywords: Product Placement, Interest.}

\section{INTRODUCTION}

The interest in using services is a description of the theory of purchase intention. Interest in buying is still a significant concern that is examined every year in marketing management because purchase intention is vital for companies, so consumers consider purchasing decisions on their products. The company will advance if the level of consumer purchase intention in the product is high. This is following an opinion [1] that purchase intention is the tendency of consumers to buy a brand or take actions related to purchases measured by the level of likelihood consumers make a purchase.

Research on consumer purchase intention has been carried out in various industries such as the retail industry [2], the games industry [3], the cosmetics industry [4,5] food industry $[6,7]$ and the tv program industry [8], the mobile apps industry [9], the online transportation industry [10].

The development of the online transportation industry in Indonesia is proliferating. The phenomenon of motorcycle taxis and online taxis is indeed endemic in Indonesia. The presence of mobile applications that sell online transportation services changes the way people order transportation modes easily and quickly, only by using a smartphone device. Even online motorcycle taxis are transformed into the mainstay of many people in
Indonesia. Online research conducted by Shopback recently proved that more than $91 \%$ of respondents claimed to have used online transportation services. Even those who have never used online transportation services also claim to be interested in using this service [11].

The application of online transportation services is now widely downloaded by people in Indonesia. Go-Jek, Uber, and Grab are the three leading providers of online transportation services. The Go-Jek application's first appearance in 2015 became the beginning of the rise of online transportation in In-donesia. More than half $(51.1 \%)$ of respondents said that Go-Jek was the first online transportation they used, followed by Grab (34.2\%) and Uber (14.4\%). The online motorcycle taxi application boom is also inseparable from the increasing internet penetration and smartphone users in Indonesia [11].

Grab still lost to Go-Jek in the category of online transportation services. Grab's lack of response also occurs if there are complaints or input from users [12]. Grab is online application-based transportation that just entered. Reportedly this online transportation often obeys its competitors who first entered the market in Indonesia, namely Go-Jek. There is a difference between Grab and Go-Jek above because the Malaysian application does not reach the respondents' locations [13]. Grab does many price promos, but many users complain because if the 
order uses the promo, drivers' response will take a longer time. Grab's promo rewards also often cannot be used so that what is promoted by Grab cannot be felt by users [14].

In fact, in buying a product, consumers will com-pare the products they will buy with other products and the benefits obtained. This is because in buying a product, consumers want to fulfill their needs and satisfy their desires. A decrease in consumer purchase intention can occur due to a lack of consumers' awareness or attention towards these products. Lack of attraction can also lead to a low interest in buying someone, and a lack of feeling of wanting to have a low product can also result in someone's purchase intention being low [15].

If a decrease in purchasing intention occurs, this will threaten the sustainability of the company. This is in line with the opinion expressed by [16] that when consumers $\&$ no longer feel happy and satisfied about a product or service offered, it will impact dissatisfaction and usually eliminate someone's interest in the product or service.

Some studies suggest factors that influence the increased interest in the use, including individual attitudes [17], information [18], brand name, price, quality, recreation, innovation awareness, promotion [19,20] product placement [21-23].

Product placement is known as brand placement in a TV program, film, etc. The integration between product brands and the media they occupy is a marketing activity and promotions that include the brand name, product, packaging, marks, and characteristics of the product into a container or media, which essentially has the purpose of placing this product commercially [24]. The existence of product placement into a media makes it easier for consumers to learn and recall from emerging product brands to the point where consumers feel interested because the product placement itself will be directly related to the creation of consumer purchase intention in the product [25].

Thus, this study aims to determine the effect of product placement on the interest in using services.

\section{METHODS}

This study consists of dependent variables, namely interest in using (Y) and independent variables, namely product placement $(\mathrm{X})$. The method used is an explanatory survey, and the respondent is the audience who commented on the Indonesian idol 2018 youtube channel. This research was conducted in less than one year, so this study uses a cross-sectional method, the research method by studying objects in a certain period of time (not sustainable over a long period of time), from April to August 2018

Research data comes from primary data sources obtained by researchers directly from the first hand through a questionnaire that will be distributed to several respondents under the target and considered to represent the entire study population. What are the audience who commented on Indonesian idol 2018 youtube channels and secondary data sources, which are obtained indirectly through publications and non-publication sources, including literature, articles, journals, and internet studies related to the research conducted.

The number of population-based on the data from the comments column in 4 videos spread on Indonesian Idol youtube channels the number of commentators was 807 people with a sample of 146 people.

Data analysis using simple linear regression analysis techniques because this study analyzes two variables. Simple linear regression analysis is a linear relationship between one independent variable $(\mathrm{X})$ with the dependent variable $(\mathrm{Y})$. This analysis is conducted to determine the direction of the relation-ship between the product placement variable (independent) and the variable interest in using (dependent), whether positive or negative and to predict the variable's value if the value of the independent variable decreases or increases.

Statistically, the hypothesis that will be tested in order to decide to accept or reject a hypothesis can be formulated as follows:

Ho: $\rho \leq 0$, meaning there is no effect of product placement on interest in using

Ha: $\rho>0$, meaning that there is an effect of prod-uct placement on interest in using.

\section{RESULTS AND DISCUSSION}

By using the SPSS 24.0 for the windows program, the regression coefficient results obtained in Table 1 below:

Table 1. Simple liniear regression model

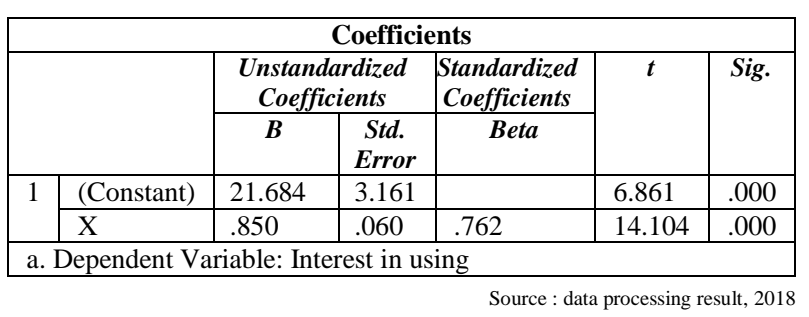

Table 1 above in column B shows constant values and simple linear regression coefficients for independent variables. From these values, we can determine the simple linear regression model expressed in the form of equations (1) as follows:

$\mathrm{Y}=\mathrm{a}+\mathrm{bX}$

$$
y=21,684+0,850 x
$$

Based on the simple linear regression equation above, a constant value of 21,684 states that if there is no product 
placement, then the amount of interest to use is 21,684. The regression coefficient in the product placement variable is 0.850 , which means that if there is an increase in the product placement value, there will be an increase in interest in the use of 0.850 . Conversely, if there is a decrease in interest, use is equal to 0.850 one unit of value. Then it can be said that product placement built by the company will affect the level of interest in using.

While the hypothesis testing in this study is in-tended to determine whether or not the influence of the product placement variable on interest in using, is shown in Table 2 below:

Tabel 2. Test calcuation result $\mathrm{t}$

\begin{tabular}{|c|c|c|c|c|c|c|}
\hline \multicolumn{7}{|c|}{ Coefficients } \\
\hline & & \multicolumn{2}{|c|}{$\begin{array}{l}\text { Unstandardized } \\
\text { Coefficients }\end{array}$} & \multirow{2}{*}{\begin{tabular}{|c|}
$\begin{array}{c}\text { Standardized } \\
\text { Coefficients }\end{array}$ \\
Beta
\end{tabular}} & \multirow[t]{2}{*}{$t$} & \multirow[t]{2}{*}{ Sig. } \\
\hline & & $B$ & $\begin{array}{c}\text { Std. } \\
\text { Error }\end{array}$ & & & \\
\hline \multirow[t]{2}{*}{1} & (Constant) & 21.684 & 3.161 & & 6.861 & .000 \\
\hline & $\mathrm{X}$ & .850 & .060 & .762 & 14.104 & .000 \\
\hline
\end{tabular}

In table 2 above, it can be seen that the amount of $\mathrm{t}$ count is 14.104 with $\mathrm{t}$ table 1.655 so that $\mathrm{t}$ count $>\mathrm{t}$ table $(14.104>1.655)$ then the decision that can be taken is that $\mathrm{HO}$ is rejected and $\mathrm{Ha}$ is accepted. This means that product placement affects the interest in using.

In table 2 above, it can be seen the magnitude of $\mathrm{t}$ count is 14.104 with $t$ table 1.655 so that $t$ count $>t$ table $(14.104>1.655)$ then the decision that can be taken is that $\mathrm{HO}$ is rejected and $\mathrm{Ha}$ is accepted. This means that product placement affects the interest in using.

Analysis of the coefficient of determination ( $R$ square) aims to determine how much the ability of the independent variable $(\mathrm{X})$ to the dependent variable $(\mathrm{Y})$. The results of the determination tests that have been carried out are shown in Table 3 below:

Table 3. Output model summary

\begin{tabular}{|c|c|c|c|c|}
\hline \multicolumn{5}{|c|}{ Model Summary } \\
\hline Model & $\boldsymbol{R}$ & $\boldsymbol{R}$ Square & $\begin{array}{c}\text { Adjusted } \boldsymbol{R} \\
\text { Square }\end{array}$ & $\begin{array}{c}\text { Std. Error of the } \\
\text { Estimate }\end{array}$ \\
\hline 1 &, $762 \mathrm{a}$ &, 580 &, 577 & 4,164 \\
\hline
\end{tabular}

Source : data processing result, 2018

To find out the magnitude of the percentage effect of product placement on the interest in using, then the calculation of the coefficient of determination is used:

$\mathrm{KD}=\mathrm{r} 2 \times 100 \%$

$$
\begin{aligned}
& =(0,762) 2 \times 100 \% \\
& =0,580644 \times 100 \% \\
& =58,0644=58 \%
\end{aligned}
$$

Based on the calculation above, the correlation or relationship ( $\mathrm{R}$ square) magnitude is equal to 0.782 . From these outputs, the coefficient of determination (R square) is 58,0644 , or $58 \%$. In contrast, the remaining $42 \%$ is influenced by other factors outside of product placement. The recapitulation of the effect of product placement on interest in using is shown in Figure 1 below:

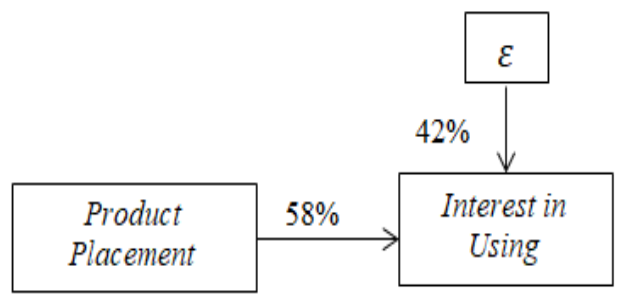

Figure 1 Effect of product placement on interest in using

After conducting a simultaneous test with significant results, the overall product placement variable affects the use. The conclusion is that product placement has a robust relationship with interest in using, where the value of the correlation ( $\mathrm{r}$ ) is $58 \%$, meaning that the change in interest in using interest is $58 \%$ influenced by product placement while other factors outside of research influence $42 \%$.

From testing, the performance of product placement can be known through the Anova or F test table, where the $\mathrm{F}$ count is 197,190 with a significance level of 0,000 , which is smaller than the significance level of $5 \%$. Meanwhile, $\mathrm{F}$ table $=3.91$ due to $\mathrm{F}$ count $>\mathrm{F}$ table, which is $197,190>3.91$, it can be concluded that Ho is rejected, meaning that there is a linear relationship between product placement and interest in using.

Hypothesis testing is done by comparing t count with $t$ table calculation of the significance test using alpha 0.05 on the one-party test with degrees of freedom $(\mathrm{dk})=\mathrm{n}-2$, $(\mathrm{dk})=146-2=144$ obtained by $\mathrm{t}$ count and table with error $5 \%$. Based on the terms of the hypothesis accepted $\mathrm{t}$ count $>\mathrm{t}$ table, it is known that the price $\mathrm{t}$ count $=14.104$ $>\mathrm{t}$ table $=1.655$, so it can be concluded that there is a positive influence between product placement and interest in using.

The statement was obtained through testing hypotheses using simple linear regression. The regression shows the change in interest correctly using (Y) that occurred following product placement changes (X) which were equal to 14.104 . This means that if there is no product placement performance $(X=0)$, then interest in using 14,104 is a unit of value. Regression coefficient 0.850 one unit of value means that every increase in product placement performance will increase interest in using by 0.850 one unit of value, and vice versa if a decrease in product placement will reduce interest in the use of 0.850 one unit of value $(Y=14.104+0.850 \mathrm{X})$ where the coefficient of determination (KD) that is by squaring the correlation coefficient obtained by $58 \%$. 
This means that the application of product placement can affect interest in using by $58 \%$.

This research is in line with the research conducted [26-28], which states that there is a positive relationship between product placement and interest in using and impacting consumer behavior in using decisions. Based on the research results on the effect of product placement on interest in using Grab, it was concluded that product placement has a strong relationship with interest in using

\section{CONCLUSIONS}

Product placement has a significant influence on interest in using. This shows that the better the brand placement that the company does, the better the consumer's interest in using the online transportation services offered by the company.

The company is expected to increase the activity of placing brands into various other media so that the Grab brand is increasingly known and in demand and continues to carry out other strategies beyond product placement such as sponsorship or special events.

\section{REFERENCES}

[1] P. Kotler, and K.L. Keller, Marketing Management, $15^{\text {th }}$ Global Ed. England: Pearson Education Limited. 2016.

[2] Rahim, S.Z. Safin, L.K. Kheng, N. Abas, and S.M. Ali, "Factors influencing purchasing intention of smartphone among university students," Procedia Econ. Financ., vol. 37, pp. 245-253, 2016.

[3] A. Adis and K. H. Jun, "Antecedents of brand recall and brand attitude towards purchase intention in advergames.," Eur. J. Bus. Manag., vol. 5, no. 18, pp. 58-67, 2013.

[4] M.B. Majid, I. Sabir, and T. Ashraf, "Consumer purchase intention towards halal cosmetics \& personal care products in Pakistan," Glob. Res. Bus. Manag., 2015.

[5] U.C. Eze, C.B. Tan, and A.L.Y. Yeo, "Purchasing Cosmetic Products: A Preliminary Perspective of Gen-Y," Contemp. Manag. Res., vol. 8, no. 1, 2012.

[6] S.H. Hassan, S.B. John Kua, and H. Harun, "Muslim consumers' perception and purchase intention toward GM food," Int. Food Res. J., vol. 23, no. 2, 2016.

[7] A.B. Halim, W.Z.W., Hamed, "Consumer purchase intention at traditional restaurant and fast food restaurant," Conf. Behav., pp. 107-112, 2005.

[8] E. Kwon and J.-H. Jung, "Product Placement in TV Shows: The Effect of Consumer Socialization Agents on Product Placement Attitude and Purchase
Intention," Online J. Commun. Media Technol., vol. 3, no. 4, pp. 88-160, 2013.

[9] C.L. Hsu and J.C.C. Lin, "What drives purchase intention for paid mobile apps?-An expectation confirmation model with perceived value," Electron. Commer. Res. Appl., vol. 14, no. 1, pp. 46-57, 2015.

[10]R. Septiani, P.W. Handayani, and F. Azzahro, "Factors that Affecting behavioral intention in online transportation service: case study of GOJEK," in Procedia Computer Science, pp. 504-512, 2017.

[11]Sering Membandingkan Harga Transportasi Online? Aplikasi Ini Akan Memudahkan Penggunanya. Shopback. 2020. [Online]. Avaible: https://www.shopback.co.id/blog/transportasionline-makin-digemari.

[12] Customer service GRAB mengecewakan.Keluhan customer diabaikan begitu saja. Lincoln96. 2020. [Online]. Avaible: https://www.kaskus.co.id/thread/59564195dcd770 a3318b4578/customer-service-grabmengecewakankeluhan-customer-diabaikanbegitu-saja/.

[13] GrabBike VS Go-Jek, Siapa yang Mencapai Pertumbuhan Paling Cepat?. Id.techinasia. 2020. [Online]. Vaible: https://id.techinasia.com/pertumbuhan-grabbikevs-go-jek.

[14] Dinamika Transportasi Online di Indonesia. Kompasiana. May 17, 2019. [Online]. Avaible: https://www.kompasiana.com/marcellamp/573b1a 76b17a612c0bd6f947/dinamika-transportasionline-di-indonesia.

[15] P. Kotler, and K.L. Keller, Marketing management. Global Ed. Harlow: Pearson Education, 2012.

[16] A. Irawan, and A. Pane, "Pengaruh segmentasi pasar terhadap minat beli pada perumahan citra garden bandar Lampung," J. Ilmiah Gema., vol. 1, no. 2, pp. 66-79 2011.

[17] C.T. Lim, J.Q. Chew, J.H. Lee, W.W. Loke, and T.K. Wong, "Exploring the factors affect-ing purchase intention of smartphone: a study of young adults in Universiti Tunku Abdul Rahman,” Ph.D. dissertation, Malaysia, 2012.

[18] R.D. Blackwell, P.W. Miniard, and J.F. Engel, J. F, Consumer behavior $9^{\text {th }}$ Ed. South-Western: Thomas Learning, 2001.

[19] C. Leo, R. Bennett, and C.E.J. Härtel, "Crosscultural differences in consumer decision-making 
styles," Cross Cult. Manag. An Int. J., vol. 12, no. 3, pp. 32-62, 2005.

[20] C. William, and E. Japarianto "Analisis pengaruh ekuitas merek terhadap minat beli konsumen ice cream di de boliva Surabaya," J. Hospitality dan Manajemen Jasa., vol. 2, no.2, pp. 1-15, 2014.

[21] I.M. You, "Product placement belief and product usage behavior in south Korea and the United States," Ph.D. dissertation, Florida., University of Florida, 2004.

[22] K.R. Lord and P.B. Gupta, "Response of buyingcenter participants to B2B product placements," J. Bus. Ind. Mark., vol. 25, no. 3, pp. 188-195, 2010.

[23] T.M. Gultom and A.K. Nan, "Pengaruh penempatan produk dan kesesuaian iklan pada minat beli yang dimoderasi sikap merek di advergames," Benefit J. Manaj. dan Bisnis, vol. 1, no. 1, pp. 79-93, 2016.

[24] K. Williams and A. Petrosky, "Product placement effectiveness: revisited and renewed.," J. Manag. Mark. Res., vol. 7, no. 1, 2011.

[25] B. Kozary and S. Baxter, "The influence of product placement prominence on consumer attitudes and intentions: A theoretical framework," Anzmac Annu. Conf., 2010.

[26] I. Brennan, K. M. Dubas, and L. A. Babin, "The influence of product-placement type \& exposure time on product-placement recognition," Int. J. Advert., vol. 18, no. 3, pp. 323-337, 1999.

[27] S.K. Balasubramanian, J.A. Karrh, and H. Patwardhan, "Audience response to product placements: An integrative framework and future research agenda," J. of Advertising. 2006.

[28] I. Brennan and L.A. Babin, "Brand placement recognition: The influence of presentation mode and brand familiarity," J. Promot. Manag., 2004. 